PROCEEDINGS OF THE UNITED STATES NATIONAL MUSEUM

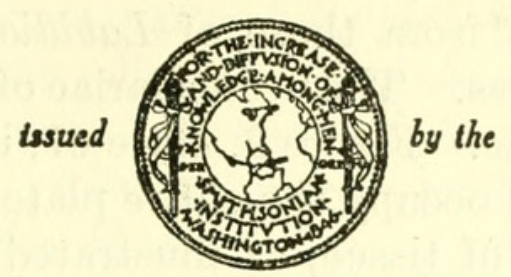

SMITHSONIAN INSTITUTION

U.S. NATIONAL MUSEUM

\title{
A NEW GENUS OF SEA STARS (PLAZASTER) FROM JAPAN, WITH A NOTE ON THE GENUS PARASTERINA
}

\section{By Walter K. Fisher}

Dr. Tohru Uchida (1928) described a new sea star from Mutsu Bay, Honshu, as Labidiaster borealis, which appeared to refute the belief that the highly specialized Labidiaster is confined to Antarctic and sub-Antarctic regions. Of this genus, described by Lütken (1871, p. 289), there are two species: L. radiosus Lütken (synonym L. crassus Koehler), distributed over the Falkland Plateau and off the southern end of South America, 0-183 m.; and L. annulatus Sladen (1889, p. 595, pl. 108, fig. 1), an Antarctic species found at Kerguelen and Heard Islands, Antarctic Archipelago, South Orkneys, South Sandwich Islands, and South Georgia, 93-44 m.

Through the kindness of Dr. R. Hayashi, Department of Zoology, Hokkaido Imperial University, Sapporo, Japan, I have received two dried specimens of Labidiaster borealis Uchida from Hokkaido. One of these is larger than any recorded by Dr. Uchida, $\mathrm{R}$ being about 180 $\mathrm{mm}$. and $\mathrm{r} 30 \mathrm{~mm}$. The specimen had 35 rays of which 10 remain.

This species is not a Labidiaster, nor does it appear to be closely enough allied to be included in the Labidiasterinae. The various polybrachiate genera of Asteriidae are not very closely related, for the development of numerous rays seems to have arisen independently in all sorts of places. We have such divergent genera, for instance, as Heliaster (usually accorded family rank), Pycnopodia, Coronaster, Rathbunaster, Labidiaster, and Saliasterias. I have recently described a rather anomalous sub-Antarctic genus, Psalidaster, distantly allied to Notasterias; and the condition in a more restrained form exists in 
genera having predominantly 5- and 6-rayed species such as Diplasterias, Lysasterias, and Cryptasterias.

The new genus, which may be called Plazaster, has crossed pedicellariae entirely different from those of Labidiaster, best understood by a comparison of figures. The pedicellariae of Labidiaster annulatus may reach enormous size. Figure 2, plate 67 , if enlarged as much as figure 1, plate 66 , would occupy the entire plate. They occur thickly on transverse cushions of tissue, as illustrated by Sladen (1889, pl. $108)$; and while those of radiosus are somewhat smaller they are still very large and of the same type as in annulatus. The shank teeth are relatively large and occur in a single series. Those of Plazaster are small and in several series. In Labidiaster much smaller pedicellariae (pl. 67, fig. 4) of several sizes occur on the thick spine sheaths, including the outer of the two adambulacral spines. In Plazaster there are no adambulacral spine pedicellariae, and none of the spinelets has a fleshy sheath, but a thin one. The absence of pedicellariae attached to one or more adambulacral spines is important in connection with their presence in Labidiaster. Adambulacral spine pedicellariae are found only in the following genera: Asterias, Evasterias, Leptasterias, Stenasterias, Perissasterias, Labidiaster, and sometimes in Urasterias as a variation. The majority of genera of Asteriidae have no adambulacral spine pedicellariae, although pedunculate straight pedicellariae, attached to adambulacral plates, are of common occurrence.

The skeleton of Plazaster is different from that of Labidiaster. The very numerous small plates form an extensive irregular net to the tip of ray, without a differentiated carinal and superomarginal system, and the inferomarginal plates alternate with an interpolated secondary ossicle. In Labidiaster the skeleton of the outer half or two-thirds of ray undergoes reduction to widely spaced transverse arches, which in old specimens degenerate to the rudiments of the marginals and a few tiny abactinals. The thick ruffs of giant pedicellariae overlie these disappearing or vanished skeletal arches. The rays of Labidiaster like those of Pycnopodia are very flexible. Both animals can catch active prey.

It is difficult to name the genus to which Plazaster is most closely related and therefore to place it satisfactorily in the system. It differs from the Labidiasterinae in the type of reticulate skeleton, in the inferior status of the marginal plates, and in lacking prominent stoles of pedicellariae on the principal spines. At the same time the ambulacral plates are rather too primitive and uncrowded for the Asteriinae. The genus is in fact very isolated. The weak but complete skeleton, in conjunction with the primitive ambulacrals, suggests the Pedicellasterinae. All known species in this subfamily have five or six rays and lack an adoral carina, the first pair of adam- 
bulacrals behind mouth plates being at least partly separated. But no species with numerous crowded rays can very well be constructed on the plan of the asteriid actinostomial skeleton and at the same time dispense with a strong adoral carina such as Plazaster possesses.

Plazaster has a stout pillar of plates extending from the odontophore to the dorsal wall, and involved in the partly membranous interbrachial septum. Such a buttress might seem to be an adaptation required by the broader disk. Psalidaster and Labidiaster have such a buttress, although Rathbunaster with a smaller disk and deciduous rays has not. The ordinary small Pedicellasterinae do not need a buttress to support the disk. "The dorsoventral pillar is characteristic of the Coscinasteriinae also, without relation to size of disk; but in this group the ambulacrals become increasingly crowded and the carinal and marginal systems of plates are strongly developed, with voluminous stoles of pedicellariae on the spines. Nor is Plazaster close to the Pycnopodiinae (Lysastrosoma, Pycnopodia), which have very compressed ambulacrals like the Asteriinae.

Possibly the best disposition of Plazaster is to regard it as a polybrachiate offshoot of the Pedicellasterinae, differing principally in having a long adoral carina.

PLAZASTER, new genus

Rays $22^{1}$ to 35 ; skeleton reticulate with very numerous irregular meshes extending to end of rays; plates small, usually with one small acicular spinelet; superomarginals not differentiated or joined in longiseries; inferomarginals small, monacanthid or diplacanthid, alternating with a secondary spineless plate and joined directly to adambulacrals; no rudimentary actinals; adambulacrals diplacanthid or triplacanthid, without spine pedicellariae; integument thin and crossed pedicellariae attached in circles at base of spinlets; crossed pedicellariae with jaw expanded distally bearing two enlarged lateral teeth; shank teeth numerous, small, in several longiseries; gonads two to a ray, opening dorsolaterally at about diameter of disk distant from base; a membranous interbrachial septum with strong dorsoventral pillar of plates from odontophore.

Type, Labidiaster borealis Uchida.

\section{PLAZASTER BOREALIS (Uchida)}

Plates 66, 68, 69

Labidiaster borealis UсHгDA, 1938, p. 800, fig. 9, pl. 33, figs 1, 2 (young).

Description.-R $180 \mathrm{~mm}$., r $30 \mathrm{~mm}$., $\mathrm{R}=6 \mathrm{r}, 35$ rays. $\mathrm{R} 60 \mathrm{~mm}$., r $12 \mathrm{~mm}$., $R=5 \mathrm{r}$, 33 rays. The skeleton is an irregular net of very numerous small plates, usually 3 -lobed at the nodes, elsewhere irregu-

${ }^{1}$ Specimen with R $30 \mathrm{~mm} ., \mathrm{r} 5.5 \mathrm{~mm}$. (Uchids). 
larly oblong. On the disk the skeletal intervals are very smallabout the size of the primary lobed plates-but on the rays they are more open, especially above the inferomarginals where they are very large. The inferomarginals, which are applied to the outer end of the adambulacral plates, are 3-lobed and not directly imbricated: There is a secondary elliptical ossicle between any two. The inferomarginals proximally often have two acicular spines the length of three adambulacral plates but usually there is one. Applied to upper lobe of inferomarginals is an oblong plate, not different from others above it, which probably represents the superomarginal. But there is no clearly differentiated series of superomarginals or of carinal plates. The latter can not be distinguished from among the numerous abactinal plates.

Most of the abactinal plates carry a slender, sharp spinelet 1 to $1.5 \mathrm{~mm}$. long, surrounded at the base by four or five crossed pedicellariae, 0.35 to $0.45 \mathrm{~mm}$. long, having one prominent tooth on each side of the tip of jaw and very numerous shank teeth in several longiseries. In the aggregate these pedicellariae are very numerous, but thin out on the sides of ray, proximally. The proximal inferomarginal spinelets usually carry basally only one or two small lanceolate straight pedicellariae but beyond middle of ray are equipped with a circlet of crossed pedicellariae. The straight pedicellariae are also scattered over the surface of the body, usually on papular areas, and are one-half to three-fourths the length of spinelets. Papulae numerous but difficult to determine accurately because the specimens have been dried. On the disk each small mesh has one papula.

The adambulacral plates are short, rather broad, and characteristically curved. They carry three slender spines, obviously longer than the inferomarginals and without any attached pedicellariae. However, on the furrow face of the plate, near base of the furrow spine, one or more pedunculate straight pedicellariae of different sizes usually occur. The adambulacral and oral spines are the longest of the body and form a dense cheval-de-frise on either furrow margin. The small mouth plates each carry one prominent suboral and two often flattened actinostomial spines, as well as a variable number of pedunculate lanceolate straight pedicellariae. The adoral carina is composed of the first seven pairs of adambulacral plates; the first five may carry three, two, or occasionally only one spine.

In Labidiaster the mouth plates of good-sized specimens become so crowded that the inner or actinostomial angle meets and fuses with that of the opposite side of furrow in such a manner that the radial nerve has to pass through a hole arched over by these fused plates. In Plazaster there is no fusion of the mouth plates. For one thing the actinostomial border of the plates is not so expanded as in Labidiaster. 
The madreporite, $4.5 \mathrm{~mm}$. in diameter, is situated at mid-r.

There are two gonads in each ray. Each consists of a bunch of branched slender lobes attached to the dorsolateral body wall $35 \mathrm{~mm}$. from the base of ray.

A short pillar of plates unites the odontophore with the abactinal skeleton as an obvious support. From and including this pillar a membranous septum passes interradially to the margin of disk, where it again becomes fortified by a short septum of plates proceeding inward from the margin. These plates are continuous with the skeleton of side of ray, the lowermost elements of the septum being marginal plates.

The ambulacral plates are not particularly thin or compressed, and the ambulacral pores form a straight, not zigzag, series. The tubefeet, arranged in two series, are apparently fairly large and crowded in the narrow ambulacral grove. The ampullae are simple, not bilobed.

Type locality.-Mutsu Bay, northern Honshu, Japan.

Specimen described, Hokkaido, Japan, U.S.N.M. No. E. 5952.

Distribution.-Northern Honshu and Hokkaido, Japan.

\section{NOTE ON THE GENUS PARASTERINA}

In the literature on sea stars there have been two quasidistinct genera bearing the name Patiria. They started as follows:

1. Patiria Gray, 1840, type P. coccinea Gray, monotypic. In 1847 Gray enlarged the genus to include granifera Gray, ocellifera Gray, obtusa Gray, and crassa Gray.

2. Patiria Perrier, 1875. "En adoptant ici le genre Patiria de Gray nous changeons notablement les limites et la charactéristique de ce genre." Perrier discarded Gray's type, coccinea, and included only ocellifera and crassa, the last obviously different from coccinea and granifera. Sladen (1889, p. 384) adopted Perrier's genus, omitting coccinea from the list of included species, to which he added a new one, bellula from Cape of Good Hope.

Gray's Patiria became submerged in the more extensive Asterina of Nardo, 1834.

Perrier's Patiria was stated to differ from Asterina in having the dorsal ossicles convex, nearly circular and touching one another, not imbricated as is ordinarily the case in Asterina. Sladen (1889, p. 376) differentiated the two groups as follows:

Abactinal plates not imbricated; covered with spines: Patiria.

Abactinal plates imbricated throughout the abactinal area, or only in definite regions: Asterina, Nepanthia, Disasterina.

This seemed to be a sound distinction; and, as Patiria Perrier was obviously invalidated by Patiria Gray, I renamed Perrier's group Parasterina, type Patiria crassa Gray (Fisher, 1908, p. 90). 
In 1913 Verrill subdivided Asterina and resuscitated Patiria Gray for the common Pacific coast Asterina miniata (Brandt). Mortensen (1933, p. 257) has ascertained that Gray's Patiria coccinea is actually this P. miniata (Brandt) and has published a photograph of one of the types. Even if the type should prove to be a specimen of the Japanese $P$. pectinifera it will make no difference, as the two species are closely related.

I recently examined specimens of Patiria granifera Gray and P. bellula Sladen from the Cape region, South Africa (pl. 70, fig. 1). Both belong to Gray's Patiria (not to Parasterina) and are probably two formae of the same species. Callopatiria Verrill, 1913, type Patiria bellula Sladen, is a synonym of Patiria Gray.

Now I have discovered that the alleged distinctive character of Parasterina does not exist in the type species! Through the kindness of Dr. H. L. Clark I have been able to study a specimen of Patiria crassa from near Fremantle, Western Australia. This specimen has R $45 \mathrm{~mm}$., r $10 \mathrm{~mm}$., br 11-12 mm., and the abactinal aspect resembles superficially that of Nardoa variolata, as the convex primary plates are spaced and the spinelets extremely fine, close-set, and visible only under strong magnification. The species is quite unlike a true Patiria but resembles Nepanthia. In fact the actinal surface does not differ from that of Nepanthia (e. g., N. belcheri) in any important particular. The actinal plates are covered with coordinated groups of very numerous spinelets. There are 15-18 similar subambulacral spinelets, and 8 or 9 furrow spinelets. The inner longiseries of actinal plates extends to three or four inferomarginals short of the end of ray; the next two series nearly as far; the fourth series about three-fifths length of ray measured on side; while a fifth and a sixth series constitute a small additional chevron in the interbrachial angle.

The two series of marginal plates are quite regular, and correspond, plate to plate; they are obviously larger than the adjacent abactinals and actinals, which are small.

There are two differentiated areas on the abactinal surface: (1) A lateral triangular area reaching at interradius, one-half $\mathrm{r}$ toward center of disk and distally nearly half length of ray; from this point it extends usually as a double series of plates nearly to tip of ray. The plates of this area, in regular longiseries, strongly imbricate, and the upper margin is excavated to accommodate a papula (fig. 21). Around this papular opening are two to four small superficial plates. Nearly all the plates carry a spiniform pedicellaria. (2) The other area, that of the convex primary plates, comprises the central part of disk and rays. It broadens distally to include most of the sides of ray also (pl. 70, fig. 2). The roundish and irregular, convex, almost tuber- 


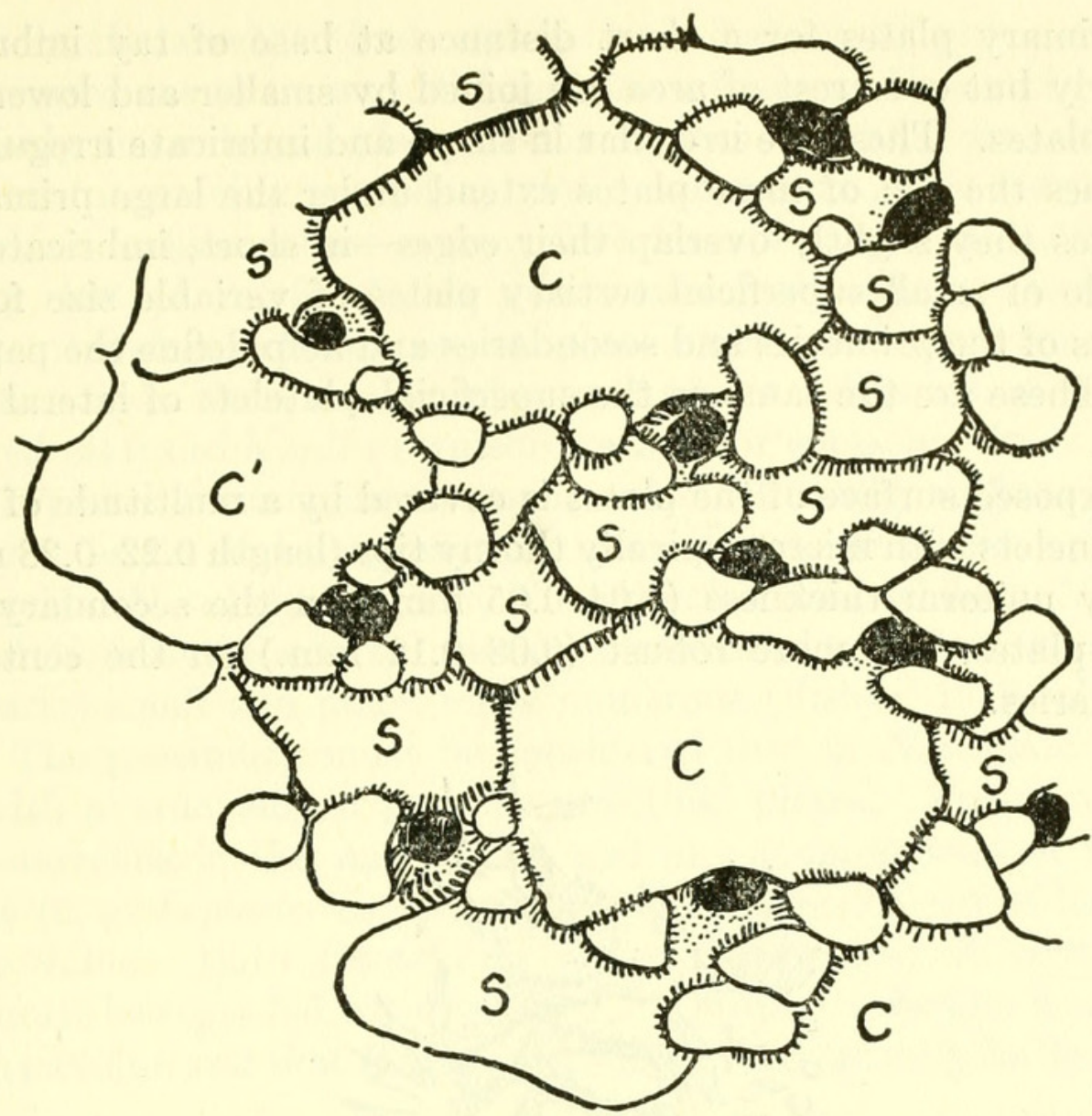

Figure 20.-Nepanthia crassa (Gray): Abactinal plates near base of ray, $\times 20$. C, carinals; $S$, secondary plates; tertiaries not lettered. Black areas are papular pores. Hatching indicates border of plate overlapped by adjacent plate. When hatching is on both sides of boundary line there is no overlapping.

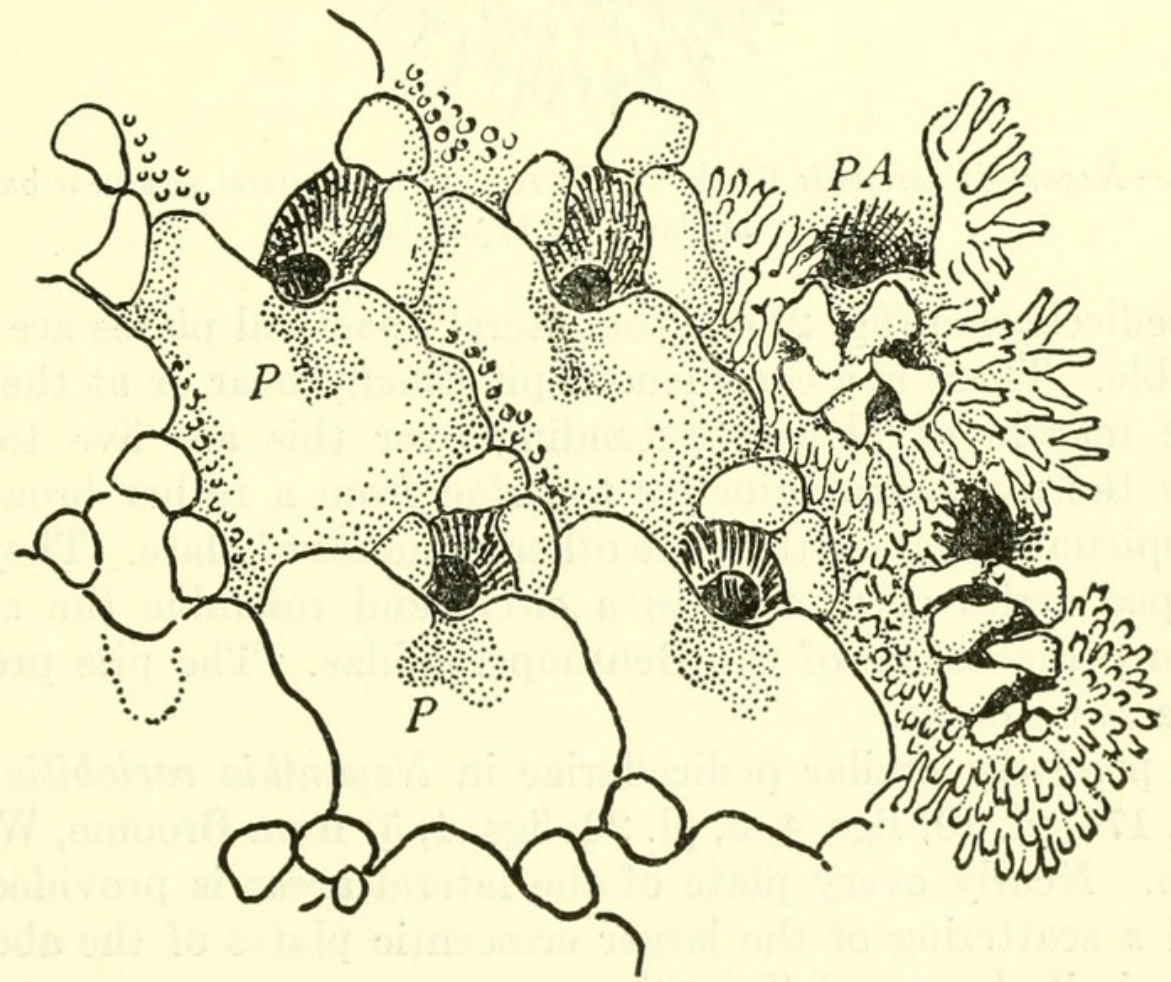

Figure 21.-Nepanthia crassa, $\times 20$ : Six lateral plates of the third and fourth series above superomarginals near base of ray, to show pedicellariae (right). Four plates are denuded to show their shape and the pedicellaria pits $(P, P)$. $P A$, papular pore. 
cular primary plates for a short distance at base of ray imbricate irregularly but over rest of area are joined by smaller and lower secondary plates. These are irregular in shape and imbricate irregularly. Sometimes the end of these plates extend under the large primaries, sometimes they slightly overlap their edges -in short, imbricate. A multitude of small superficial tertiary plates of variable size fortify the joints of the primaries and secondaries and help define the papular pores. These are the same as the superficial platelets of lateral area (fig. 20).

The exposed surface of the plates is covered by a multitude of very small spinelets with microscopically thorny tips (length $0.22-0.28 \mathrm{~mm}$.) of nearly uniform thickness $(0.04-0.05 \mathrm{~mm}$.) on the secondary and tertiary plates, but more robust $(0.08-0.12 \mathrm{~mm}$.) on the center of the primaries.

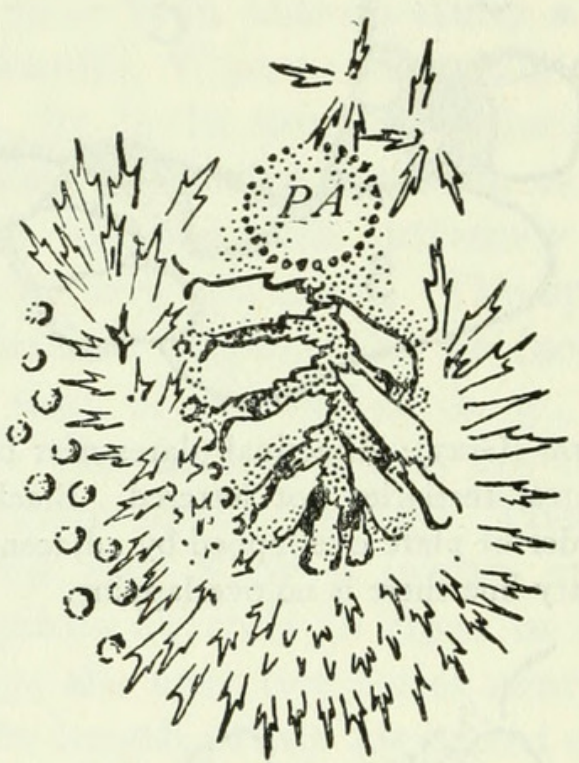

Figure 22.-Nepanthia variabilis Clark, $X$ 40: A plate from lateral area near base of ray to show pedicellaria. $P A$, papular pore.

The pedicellariae (fig. 21) of the lateral abactinal plates are rather remarkable. There is a conspicuous pit usually near or at the upper excavate margin of plate. Extending over this are five to eight minutely thorny, sharp spinelets tapering from a rather broad base and conspicuously larger than the other spinelets of plate. They form a U-shaped series or sometimes a circle and resemble the circular spiniform pedicellariae of the Benthopectinidae. The pits probably contain a sense organ.

I find precisely similar pedicellariae in Nepanthia variabilis Clark (1938, p. 176, pl. 10, figs. 4, 5, pl. 20, figs. 4, 5) from Broome, Western Australia. Nearly every plate of the lateral areas is provided with one, and a scattering of the larger crescentic plates of the abactinal area, are similarly armed (fig. 22). 
The adambulacral, actinal, and the lateral abactinal plates of Parasterina crassa are in no way different from those of Nepanthia. This leaves only the enlarged plates of the median abactinal area with the numerous intervening secondary plates and superficial tertiary plates upon which to base a new genus. But Parasterina occidentalis Clark (1938, p. 180, pl. 21, fig. 5) has no secondary abactinals. It is questionable, therefore, whether we can place too much reliance for generic characters upon these median abactinal plates. The behavior of the abactinal plates of Nardoa furnishes reason for caution. In N. pauciforis the plates are numerous, small, and most nearly uniform in size. Somewhat larger and progressively more diverse as to size are those of $N$. mollis, N. tuberculata, and N. novaecaledoniae, while in N.tumulosa and $N$. frianti the large primary plates are hemispherical and the secondaries small and much more numerous (Fisher, 1919, pls. 108110). The possibility must be considered that in Nepanthia species exist with overdeveloped primary abactinal plates. They are not a rare occurrence in the Asteroidea, and in certain species of the Asteriidae (e. g. Leptasterias polaris, Pisaster ochraceus) are of less than specific value. Both Parasterina crassa (Gray) and P. occidentalis Clark must be regarded with suspicion. I think the former is an aberrant Nepanthia, and that Parasterina should consequently be discarded. 


\section{LITERATURE CITED}

Clark, Hubert Lyman.

1938. Echinoderms from Australia. An account of collections made in 1929 and 1932. Mem. Mus. Comp. Zool., vol. 55, 596 pp., 28 pls.

Fisher, Walter Kenrick.

1908. Necessary changes in the nomenclature of starfishes. Smithsonian Misc. Coll., vol. 52, pp. 87-93.

1911. Asteroidea of the North Pacific and adjacent waters. Part 1, Phanerozonia and Spinulosa. U. S. Nat. Mus. Bull. 76, 419 pp., 122 pls.

1919. Starfishes of the Philippine Seas and adjacent waters. U. S. Nat. Mus. Bull. 100, vol. 3, 712 pp., 156 pls.

Gray, John Edward.

1840. A synopsis of the genera and species of the class Hypostoma (Asterias Linn.). Ann. Mag. Nat. Hist., ser. 1, vol. 6, pp. 175-184, 275-290.

1847. Descriptions of some new genera and species of Asteriadae. Proc. Zool. Soc. London, 1847, pp. 72-83.

Lütken, Christian Frederick.

1871. Forsatte kritiske og beskrivende Bidrag til Kundskab om Søstjernerne (Asteriderne). Vid. Medd. Nat. Foren., Kjøbenhavn, 1871, pp. 289, 293.

Mortensen, Theodor.

1933. Echinoderms of South Africa (Asteroidea and Ophiuroidea). Vid. Medd. Dansk Nat. Foren. vol. 93, pp. 215-400, pls. 8-19.

\section{Perrier, Edmond.}

1875. Révision de la collection de stellérides du Muséum d'Histoire Naturelle de Paris. $384 \mathrm{pp}$.

Sladen, W. Percy.

1889. Report on the Asteroidea collected by H. M. S. Challenger, Zoology, vol. 30,893 pp., 117 pls.

UCHIDA, TOHRU.

1928. Report of the biological survey of Mutsu Bay. II, Starfishes of Mutsu Bay. Sci. Rep. Tohoku Imp. Univ., ser. 4, vol. 3, No. 4, fasc. 2, pp. 785-803, pls. 31-33.

Verrill, AdDison Emery.

1913. Revision of the genera of starfishes of the subfamily Asterininae. Amer. Journ. Sci., vol. 35, pp. 477-485. 


\section{$2 \mathrm{BHL}$ Biodiversity Heritage Library}

Fisher, Walter K. 1941. "A new genus of sea stars (Plazaster) from Japan, with a note on the genus Parasterina." Proceedings of the United States National Museum 90, 447-456. https://doi.org/10.5479/si.00963801.90-3114.447.

View This Item Online: https://www.biodiversitylibrary.org/item/32375

DOI: https://doi.org/10.5479/si.00963801.90-3114.447

Permalink: https://www.biodiversitylibrary.org/partpdf/14468

\section{Holding Institution}

Smithsonian Libraries

\section{Sponsored by}

Smithsonian

\section{Copyright \& Reuse}

Copyright Status: NOT_IN_COPYRIGHT

Rights: https://www.biodiversitylibrary.org/permissions/

This document was created from content at the Biodiversity Heritage Library, the world's largest open access digital library for biodiversity literature and archives. Visit BHL at https://www.biodiversitylibrary.org. 